ISSN 1392-3196 / e-ISSN 2335-8947

Zemdirbyste-Agriculture, vol. 104, No. 3 (2017), p. 243-248

DOI 10.13080/z-a.2017.104.031

\title{
Genotypic and exogenous factors affecting linseed ovary culture
}

\author{
Aušra BLINSTRUBIENĖ, Natalija BURBULIS, Ramunė MASIENE் \\ Aleksandras Stulginskis University \\ Studentų 11, Akademija, Kaunas distr., Lithuania \\ E-mail: ausra.blinstrubiene@asu.lt
}

\begin{abstract}
The current study investigated the effect of genotype, growth regulators and type of carbohydrates on callus induction and indirect shoot regeneration in ovary culture of 8 linseed (Linum usitatissimum L.) cultivars. Callogenic response varied from $9.17 \%$ to $100 \%$ depending on the cultivars and medium composition interaction. The replacement of sucrose with a combination of sucrose + maltose significantly improved the callogenesis in 3 or 4 investigated cultivars, depending on growth regulators in the induction medium. The frequency of shoot formation from ovaryderived callus in 5 responsive cultivars ranged from $4.17 \%$ to $75.00 \%$, whereas the other three cultivars tested did not exhibit any shoots. The replacement of sucrose with a sucrose + maltose combination in induction medium reduced or completely inhibited shoot formation frequency of responsive cultivars. The significantly highest mean shoot formation frequency $(52.50 \%)$ was obtained from ovary-derived callus of the cultivar 'Mikael'. The analysis of variance revealed that cultivar $(\mathrm{C})$, combination of growth regulators $(\mathrm{GR})$, type of carbohydrates $(\mathrm{CH})$ and their interaction significantly influenced callus induction and shoot formation frequency. In most cases, a higher shoot regeneration frequency was obtained when callus was from induction medium supplemented with $2 \mathrm{mg}$ $\mathrm{l}^{-1}$ thidiazuron (TDZ) $+1 \mathrm{mg} \mathrm{l}^{-1} \alpha$-naphthylacetic acid (NAA) with $6 \%$ sucrose. Cytological analysis of root tips showed that $21.88 \%$ of the regenerated plants were haploids, while another group of regenerants $(78.12 \%)$ were diploid and mixoploid.
\end{abstract}

Key words: carbohydrates, genotype, growth regulators, Linum usitatissimum, morphogenic response, ovary culture.

\section{Introduction}

Linseed (Linum usitatissimum L.) is one of the most economically important oilseed crops in many regions of the world. Linseed oil is widely used for healthy food production, in medicine, chemistry and technical industry as well as valuable feed for livestock (Tolkachev, Zhuchenko, 2000; Zuk et al., 2015). Consequently, nowadays linseed breeding is focused on improvement of fatty acids composition in order to create cultivars with a lowered $\alpha$-linolenic acid content (Pretova, Obert, 2000). Breeding efforts are needed for further development of low linolenic acid varieties, the oil of which can be widely used as cooking oil. As linseed is highly nutritious, it is necessary to reduce its anti-nutrient components and also bio-convert its less acceptable alpha-linolenic acid $(18: 3 \omega 3)$ into acceptable stearidonic acid $(18: 4 \omega 3)$. More concerted efforts for development of varieties resistant to different disease like wilt, rust, powdery mildew and Alternaria blight are also required (Yadava et al., 2012; Pavelek et al., 2015).

Development of novel genotypes by conventional breeding methods is time consuming and complicated (Mikelsone et al., 2013); therefore the development of alternative methods for producing homozygous lines is required. Development of haploids by biotechnological methods leads to the creation of homozygous genotypes in one generation; therefore a double haploid system is an extremely valuable breeding tool (Wedzony et al., 2009). Plant regeneration in vitro from isolated ovary has been achieved in some crops such as onion (Kamštaitytè, Stanys, 2002), maize (Tang et al., 2006), sugar beet (Gurel et al., 2000), wheat (Sibi et al., 2001). Lately, the overall plant regeneration frequency in flax from anther has been significantly increased by the modification of medium composition (Chen, Dribnenki, 2002; RutkowskaKrause et al., 2003; Burbulis et al., 2005) and culture conditions (Obert et al., 2004 a). However, application of ovary culture for linseed haploid production has been documented in few reports (Bartosova et al., 2003; Obert et al., 2004 b); therefore little information is available concerning the various factors that contribute to the successful gynogenesis induction. One of the most important factors for morphogenesis induction in ovary culture is a properly chosen combination of growth regulators (Chand, Sahrawat, 2007). A significant effect of the thidiazuron (TZD) on organogenesis was reported for many plants, such as Cannabis sativa L. (Lata

Please use the following format when citing the article:

Blinstrubienė A., Burbulis N., Masienė R. 2017. Genotypic and exogenous factors affecting linseed ovary culture. ZemdirbysteAgriculture, 104 (3): 243-248 DOI 10.13080/z-a.2017.104.031 
et al., 2009), Rubus fruticosus L. (Vujović et al., 2010), Cymbidium giganteum Wall. ex Lindl. (Ghosh et al., 2014). According to Guo et al. (2011), thidiazuron has strong cytokinin-like activity and stimulates effective morphogenic responses in in vitro cultures. Many research groups have reported that sucrose is the best carbon source for morphogenesis induction in vitro from all types of explants. However, it has been found that maltose is more suitable for callus formation and plant regeneration in anther culture of barley (Finnie et al., 1989), wheat (Navarro-Alvarez et al., 1994; Redha, Talaat, 2008) and flax (Tejklova, 1998). The aim of the present study was to investigate the effect of growth regulators and type of carbohydrates on morphogenic response in linseed ovary culture.

\section{Materials and methods}

Research was carried out in 2015-2016 in Institute of Biology and Plant Biotechnology of Aleksandras Stulginskis University and Laboratory of Agrobiotechnology of Joint Research Centre.

Plant material and tissue culture. Experiments were carried out with 8 linseed (Linum usitatissimum L.) cultivars: 'Atalante', 'Dnepr-2', 'Indus-2', 'Lirina', 'Mikael', 'Norman', 'Valuta-1' and 'Zaltan-1'. Seeds were germinated and grown in a growth chamber with a $16 \mathrm{~h}$ photoperiod, temperature $18 / 14^{\circ} \mathrm{C}$ (day/night) and $75 \%$ humidity. All plants were grown in a mixture of peat, vermiculite and sand at $3: 1: 2$ ratio in $16.5 \mathrm{~cm}$ pots. The plants were watered and fertilized with diluted 20:20:20 N:P:K at a rate of $4 \mathrm{~g} \mathrm{l}^{-1}$ as required.

Harvested buds (3.5-4.0 mm in length) were surface sterilized in $70 \%$ ethanol for $1 \mathrm{~min}$, then in $2 \%$ sodium hypochlorite for $10 \mathrm{~min}$ and rinsed three times with sterile distilled water. The ovaries were placed onto a plastic Petri dish containing $15 \mathrm{ml}$ of modified MS $\left(\mathrm{NH}_{4} \mathrm{NO}_{3}-165 \mathrm{mg} \mathrm{l}^{-1}\right.$ ) induction MS medium (Murashige, Skoog, 1962) solidified with $0.6 \%$ agar and incubated at $25^{\circ} \mathrm{C}$ in the dark. Combinations of cytokinin and auxin (2 $\mathrm{mg} \mathrm{l}^{-1}$ thidiazuron (1-phenyl-3-(1,2,3-thiadiazol-5-yl) urea) (TDZ) $+1 \mathrm{mg} \mathrm{l}^{-1} \alpha$-naphthylacetic acid (NAA) and $\left.1 \mathrm{mg} \mathrm{l}^{-1} \mathrm{TDZ}+2 \mathrm{mg} \mathrm{l}^{-1} \mathrm{NAA}\right)$ and carbohydrate $(6 \%$ sucrose or $3 \%$ sucrose $+3 \%$ maltose) were selected based on the results from our previous experiments (unpublished data). Every four weeks, the calli were subcultured to fresh medium and were maintained at $27 / 24^{\circ} \mathrm{C}$ (day/night) under a $16 \mathrm{~h}$ photoperiod, at a light density of $50 \mu \mathrm{mol} \mathrm{m} \mathrm{m}^{-2} \mathrm{~s}^{-1}$.

Ovary-derived calli with a diameter of more than $4 \mathrm{~mm}$ and which were produced within four weeks after ovary isolation were transferred to shoot regeneration medium contained MS mineral salts and vitamins supplemented with $1 \mathrm{mg} \mathrm{l}^{-1}$ 6-benzylaminopurine (BAP), $375 \mathrm{mg} \mathrm{l}^{-1}$ glutamine, $3 \%$ sucrose and $0.6 \%$ agar. After organogenesis induction buds were cut and transferred to a shoot elongation medium containing MS mineral salts and vitamins supplemented with $0.001 \mathrm{mg} \mathrm{l}^{-1} \mathrm{NAA}$, $0.01 \mathrm{mg} \mathrm{l}^{-1}$ BAP, $3 \%$ sucrose and $0.6 \%$ agar. The shoots regenerated from ovary-derived calli were transferred for rooting to MS medium without growth regulators and containing reduced concentrations of macro and micro salts by $50 \%$ and maintained at $25 / 22^{\circ} \mathrm{C}$ (day/night) under a $16 \mathrm{~h}$ photoperiod, at a light density of $50 \mu \mathrm{mol}$ $\mathrm{m}^{-2} \mathrm{~s}^{-1}$. Rooted plantlets were transferred to plastic pots containing sterilized soil and vermiculite at 1:1 ratio.

For establishment of the chromosome number in the regenerated plantlets, root tips were fixed in Carnoy solution (100\% ethanol:glacial acetic acid, 3:1) for 7 days. Subsequently, samples were washed thoroughly with distilled water and treated with $1 \mathrm{~N} \mathrm{HCl}$ at $60^{\circ} \mathrm{C}$ temperature for $10 \mathrm{~min}$. Then the macerated tissue was washed again and stained with Schiff reagent as described by Bartošová et al. (2005).

Statistical analysis. Experiments were set up in a completely randomized design with three replicates per treatment and 30 explants per each replicate; each experiment was done in triplicate. The percentage of callus induction: (number of explants with callus/total number of explants) $\times 100 \%$, the percentage of callus forming shoots: (number of calli with adventitious shoots/total number of calli) $\times 100$, were calculated using software STAT 1.55 from SELEKCIJA and IRRISTAT (Tarakanovas, Raudonius, 2003). Mean value of callus induction, shoot formation frequency and standard error (SE) for each cultivar were calculated based on the number of independent replications. All percentage values were transformed using arcsine square root $(\sqrt{ } \mathrm{P})($ Compton, 1994) to normalize the distribution prior to analysis of variance. Effects of factors (cultivar, growth regulators combination, carbohydrate) and their interaction on shoot formation were studied by a three-way analysis of variance. For multiple comparisons, Tukey test was used.

\section{Results and discussion}

Gynogenesis in linseed predominantly involves the organogenesis pathway in which plant regeneration is achieved from unfertilised egg cell, through an intermediate callus phase. Therefore efficient production of high-quality callus is a prerequisite for achieving efficient plant regeneration. Formation of callus was observed within three weeks after isolation of ovaries. The effect of growth regulator combination and carbohydrate type on callus induction in the tested linseed cultivars is presented in Figure 1. Callogenesis response varied depending on the cultivar and medium composition interaction. The mean values of the callus formation frequency ranged from $9.17 \%$ for the cultivar 'Indus-2' on medium with $1 \mathrm{mg} \mathrm{l}^{-1} \mathrm{TDZ}+2 \mathrm{mg} \mathrm{l}^{-1} \mathrm{NAA}$ supplemented with $6 \%$ sucrose (Fig. 1 B) to $100 \%$ for the cultivar 'Dnepr-2' on medium with $2 \mathrm{mg} \mathrm{l}^{-1} \mathrm{TDZ}+$ $1 \mathrm{mg} \mathrm{l}^{-1}$ NAA supplemented with $6 \%$ sucrose and for the cultivar 'Zaltan-1' on medium with $2 \mathrm{mg} \mathrm{l}^{-1} \mathrm{TDZ}+$ $1 \mathrm{mg}^{-1}$ NAA supplemented with $3 \%$ sucrose and $3 \%$ maltose (Fig. $1 \mathrm{~A}$ ).

In the presence of sucrose, cultivars 'Atalante', 'Mikael', 'Zaltan-1', 'Dnepr-2' and 'Indus-2' showed a higher value of responsible explants on medium with $2 \mathrm{mg} \mathrm{l}^{-1} \mathrm{TDZ}$ and $1 \mathrm{mg} \mathrm{l}^{-1} \mathrm{NAA}$, while ovaries of cultivars 'Lirina', 'Valuta-1' and 'Norman' showed a better response in a medium with $1 \mathrm{mg} \mathrm{l}^{-1} \mathrm{TDZ}+2 \mathrm{mg} \mathrm{l}^{-1} \mathrm{NAA}$. The replacement of sucrose with combination of sucrose + maltose in the induction medium supplemented with $2 \mathrm{mg} \mathrm{l}^{-1} \mathrm{TDZ}+1 \mathrm{mg} \mathrm{l}^{-1} \mathrm{NAA}$ improved the callogenesis in cultivars 'Atalante', 'Valuta-1' 'Indus-2' and 'Zaltan-1'. On media with $1 \mathrm{mg} \mathrm{l}^{-1} \mathrm{TDZ}+2 \mathrm{mg} \mathrm{l}^{-1}$ NAA the use of carbohydrates combination resulted in significant increase $(P<0.01)$ in callus formation frequency for cultivars 'Atalante', 'Zaltan-1' and 'Indus-2'. In our previous study we reported that replacement of sucrose with a combination of sucrose + maltose in induction medium supplemented with $2 \mathrm{mg} \mathrm{l}^{-1}$ BAP $+1 \mathrm{mg} \mathrm{l}^{-1}$ NAA improved the callogenesis in cultivars 'Lirina' and 'Mikael' from isolated anthers (Burbulis, Blinstrubienè, 2011). However, in the present study the 

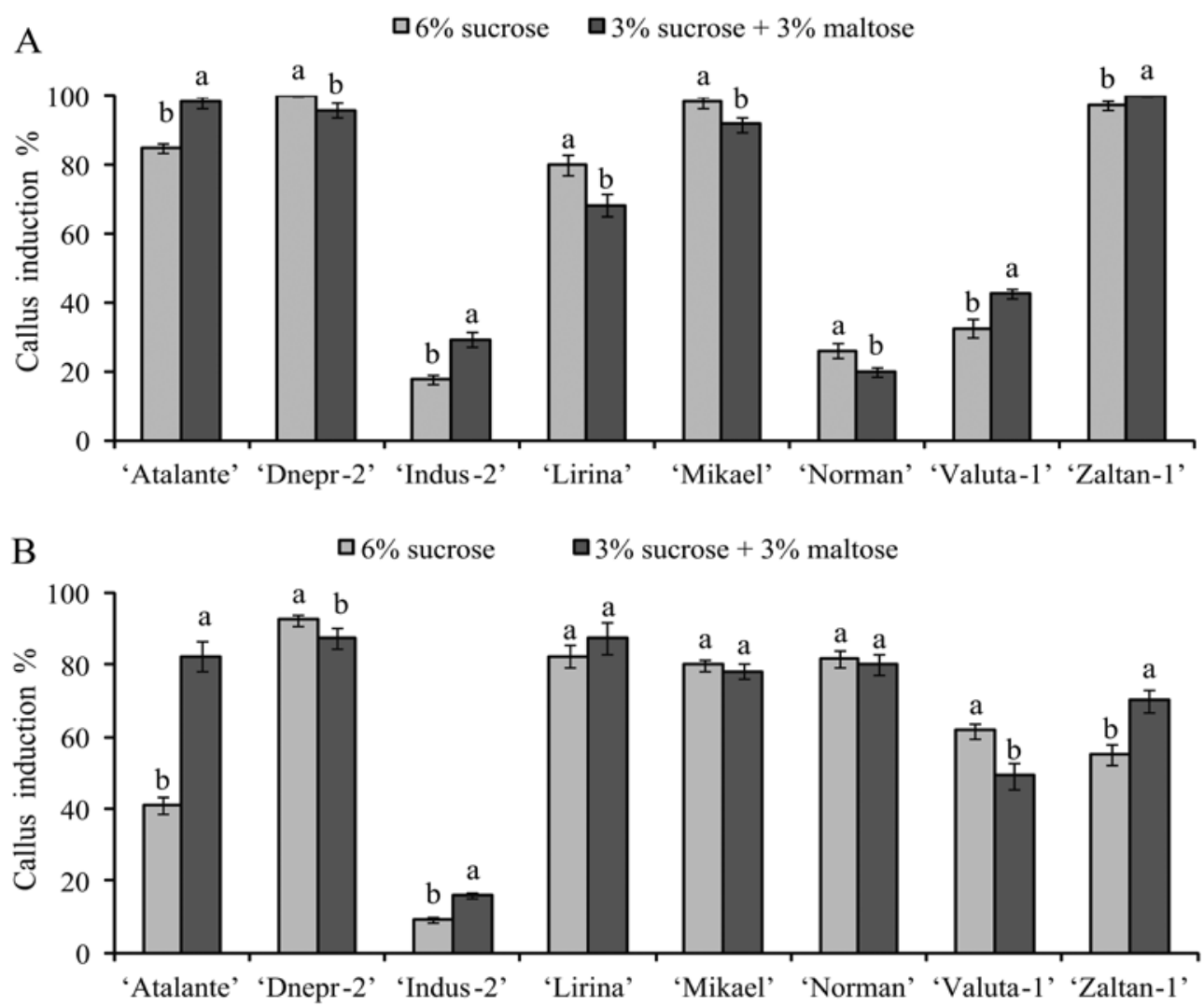

Note. A $-2 \mathrm{mg} \mathrm{l}^{-1}$ thidiazuron (TDZ) $+1 \mathrm{mg} \mathrm{l}^{-1} \alpha$-naphthylacetic acid (NAA); $\mathrm{B}-1 \mathrm{mg} \mathrm{l^{-1 }} \mathrm{TDZ}+2 \mathrm{mg} \mathrm{l^{-1 }} \mathrm{NAA}$; means $\pm \mathrm{SE}$ within a cultivar followed by the same letter are not significantly different at $P<0.01$.

Figure 1. Effect of growth regulator and carbohydrate on callus induction in ovary culture of eight linseed cultivars

use of carbohydrates combination on media with $2 \mathrm{mg} \mathrm{l}^{-1}$ $\mathrm{TDZ}+1 \mathrm{mg} \mathrm{l}^{-1}$ NAA resulted in significant decrease in callus formation isolated ovaries of these cultivars. This indicated that there are differences between anther and ovary cultures response within the same genotype.

After transfer of ovary-derived callus to the shoot regeneration medium, formation of meristemic zones and adventitious buds was observed within 2-3 weeks for cultivars 'Atalante', 'Valuta-1', 'Mikael', 'Zaltan-1' and 'Dnepr-2'. Shoot formation frequency in responsive cultivars ranged from $4.17 \%$ to $75.0 \%$ for all treatments tested (Fig. 2).
It is well documented that TDZ significantly increased shoot formation frequency from somatic tissues of different plants (Lata et al., 2009; Ghosh et al., 2014) as well as in Linum usitatissimum (Mundhara, Rashid, 2006). Diao et al. (2009) reported positive effect of TDZ on gynogenesis in ovary culture of Cucumis sativus; however, optimal concentration has been shown to be strongly genotype-dependent and must be determined for each cultivar. In the present study, induction medium supplemented with $1 \mathrm{mg} \mathrm{l}^{-1} \mathrm{TDZ}+2 \mathrm{mg} \mathrm{l}^{-1}$ NAA promoted organogenesis from ovary-derived callus of cultivar 'Atalante', while the combination $2 \mathrm{mg} \mathrm{l}^{-1} \mathrm{TDZ}$ with

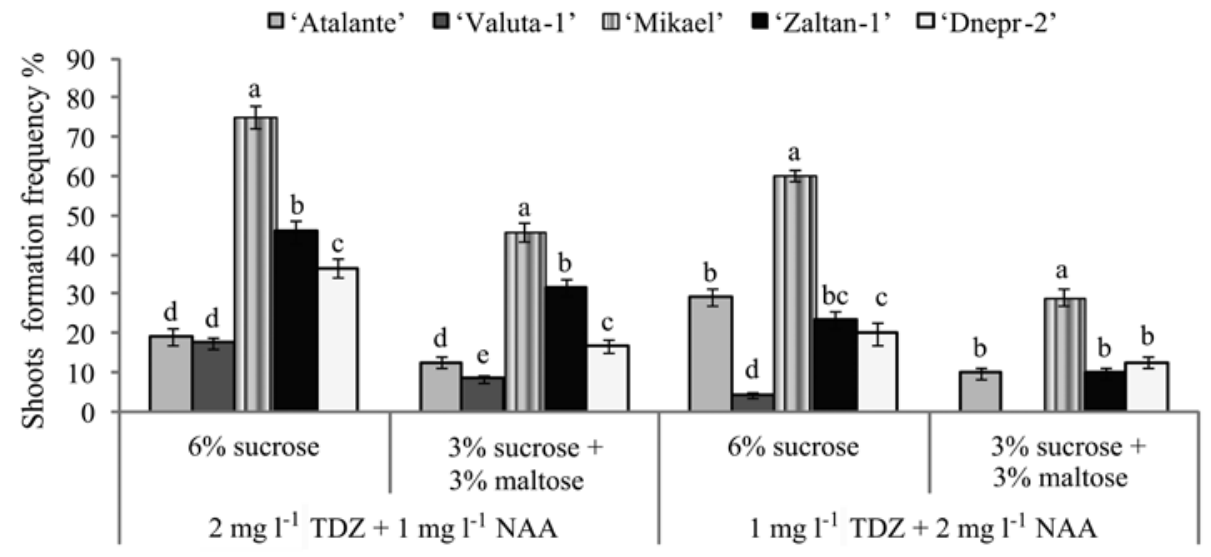

Note. TDZ - thidiazuron, NAA $-\alpha$-naphthylacetic acid; means \pm SE within a cultivar followed by the same letter are not significantly different at $P<0.01$.

Figure 2. Effect of growth regulator and carbohydrate in the induction medium on shoot formation from ovaryderived callus of responsive linseed cultivars 
$1 \mathrm{mg} \mathrm{l}^{-1}$ NAA increased shoot regeneration frequency of cultivars 'Valuta-1', 'Mikael', 'Zaltan-1' and 'Dnepr-2'. The replacement of sucrose with a sucrose-maltose combination in induction medium supplemented with $2 \mathrm{mg} \mathrm{l}^{-1} \mathrm{TDZ}+1 \mathrm{mg} \mathrm{l}^{-1}$ NAA reduced shoot formation frequency of all responsive cultivars. When ovary-derived calli were obtained on medium supplemented with $1 \mathrm{mg}$ $\mathrm{l}^{-1} \mathrm{TDZ}+2 \mathrm{mg} \mathrm{l}^{-1} \mathrm{NAA}$, the replacement of sucrose with a combination of sucrose + maltose significantly decreased organogenesis in cultivars 'Atalante' 'Mikael', 'Zaltan-1' and 'Dnepr-2', and completely inhibited shoot formation from ovary-derived callus of cultivar 'Valuta-1'. In contrast, our previous study showed that combination $3 \%$ sucrose $+3 \%$ maltose improved the shoot formation frequency from anther-derived callus of cultivars 'Lirina' and 'Mikael' (Burbulis, Blinstrubienè, 2011).

Genotypic difference is one of the most important factors, which may affect regeneration efficiency from ovary-derived callus. The ability of callus induction and shoot regeneration can vary considerably among various species of genus or among cultivars within the same species. Most of the published reports on the linseed have noted strong genotypic effect on morphogenesis in generative tissue cultures (Pretova et al., 2006; Burbulis et al., 2007; Obert et al., 2009). In the present study, significant differences in shoot formation frequency were observed among the studied cultivars.

The highest mean $(52.50 \%)$ shoot formation frequency, significantly differing $(P<0.01)$ from the other cultivars, was obtained from ovary-derived callus of cultivar 'Mikael' (Fig. 3).

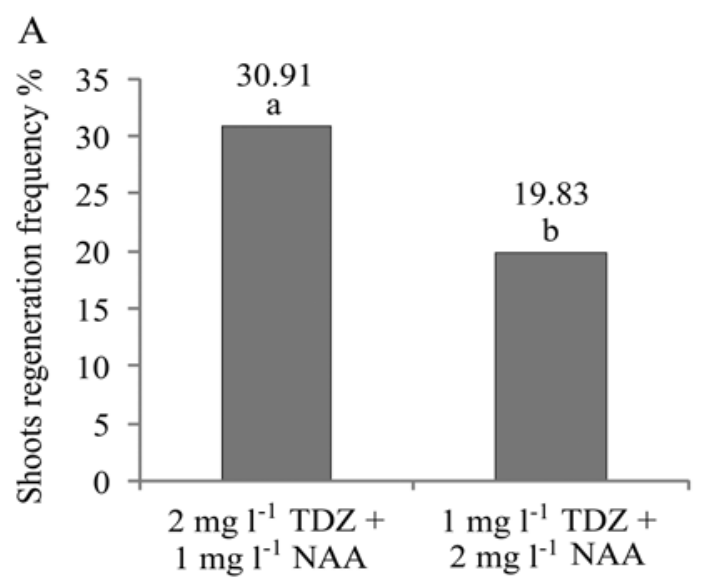

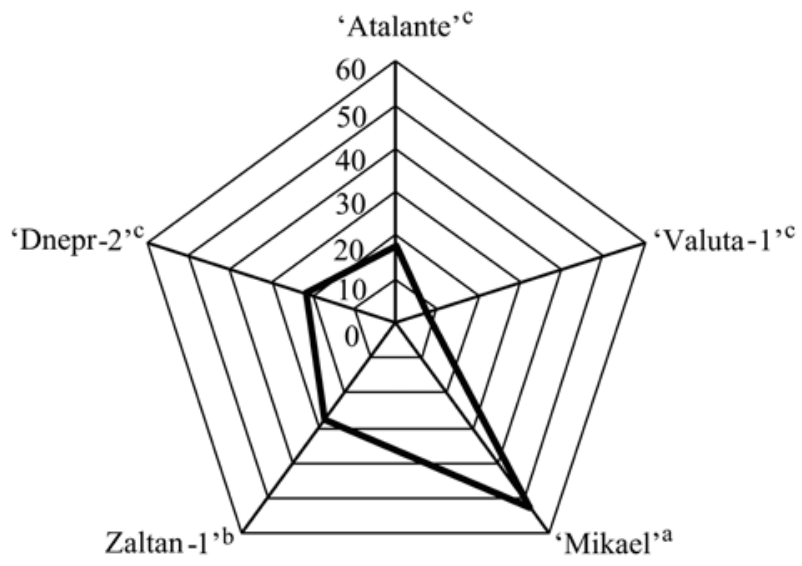

Note. Means within a cultivar followed by the same letter are not significantly different at $P<0.01$.

Figure 3. Effect of cultivars on shoot regeneration from ovary-derived callus of responsive linseed cultivars

Culture medium composition is another important factor affecting plant regeneration. Our results showed that a combination of growth regulators in the induction medium had very significant effect $(P<0.01)$ on shoot regeneration frequency from ovary-derived callus in the regeneration medium. Statistical analysis did not allow considering combinations of $2 \mathrm{mg} \mathrm{l}^{-1} \mathrm{TDZ}$ $+1 \mathrm{mg} \mathrm{l}^{-1} \mathrm{NAA}$ and $1 \mathrm{mg} \mathrm{l}^{-1} \mathrm{TDZ}+2 \mathrm{mg} \mathrm{l}^{-1} \mathrm{NAA}$ as one homogenous group (Fig. 4 A).

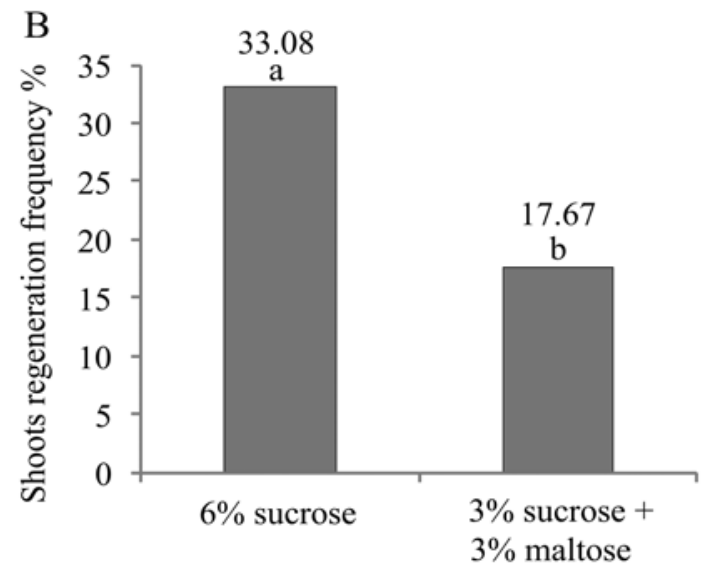

Note. TDZ - thidiazuron, NAA - $\alpha$-naphthylacetic acid; means within a growth regulators and carbohydrate combinations followed by the same letter are not significantly different at $P<0.01$.

Figure 4. Effect of growth regulators (A) and carbohydrate (B) combinations on shoot regeneration from ovaryderived callus

The level and type of carbohydrates in the culture medium are also predetermining factors in the induction of gynogenic structures. Maltose was found to be the most effective carbohydrate for shoot induction in linseed somatic tissue culture (Millam et al., 1992). The capacity of combination 3\% sucrose $+3 \%$ maltose to stimulate morphogenesis in anther culture of linseed was reported by Tejklova (1998). In the present study, the combination sucrose + maltose in the induction medium increased callus formation frequency in some cultivars (Fig. 1); however, significantly decreased shoot formation frequency from ovary-derived callus (Fig. 2). A significant effect $(P<0.01)$ of carbohydrate type in induction medium on shoot regeneration frequency from ovary-derived callus of studied linseed cultivars was observed (Fig. 4 B). The statistical analysis showed that each of the tested carbohydrate types ( $6 \%$ of sucrose alone and combination 3\% sucrose $+3 \%$ maltose) constituted one separate homogenous group.

The analysis of variance revealed that cultivar (C), growth regulators (GR) combination, type of carbohydrate $(\mathrm{CH})$ and their interaction significantly influenced callus induction and shoot formation frequency from ovary-derived callus. However, the effect of interaction $\mathrm{GR} \times \mathrm{CH}$ on shoot regeneration frequency was not significant (Table).

Cytological analysis of root tips showed that $21.88 \%$ of the regenerated plants were haploids, while another group of regenerants (78.12\%) were diploid and mixoploid. Different ploidy level of plants regenerants 
Table. Effect of different factors on callus induction and shoot formation frequency

\begin{tabular}{|c|c|c|c|c|}
\hline Effect & $\begin{array}{c}F \text {-values of callus } \\
\text { induction frequency } \\
\%\end{array}$ & $\begin{array}{l}P \text {-values for callus } \\
\text { induction frequency }\end{array}$ & $\begin{array}{c}F \text {-values of shoots } \\
\text { formation frequency } \\
\%\end{array}$ & $\begin{array}{l}P \text {-values for shoots } \\
\text { formation frequency }\end{array}$ \\
\hline Cultivar (C) & $235.08^{* *}$ & $<0.001$ & $297.68^{* *}$ & $<0.001$ \\
\hline $\begin{array}{l}\text { Growth regulators } \\
\text { (GR) combination }\end{array}$ & $39.34 * *$ & $<0.001$ & $199.75 * *$ & $<0.001$ \\
\hline Carbohydrate $(\mathrm{CH})$ & $7.88 * *$ & $<0.007$ & $324.27 * *$ & $<0.001$ \\
\hline $\mathrm{C} \times \mathrm{GR}$ & $89.17 * *$ & $<0.001$ & $25.38 * *$ & $<0.001$ \\
\hline $\mathrm{C} \times \mathrm{CH}$ & $17.32 * *$ & $<0.001$ & $6.84 * *$ & $<0.001$ \\
\hline $\mathrm{GR} \times \mathrm{CH}$ & $3.53 \mathrm{~ns}$ & 0.065 & $1.66 \mathrm{~ns}$ & 0.205 \\
\hline $\mathrm{C} \times \mathrm{GR} \times \mathrm{CH}$ & $3.01 *$ & 0.009 & $4.54 * *$ & 0.004 \\
\hline
\end{tabular}

* - significant at 5\% level $(P<0.05)$, ** - significant at $1 \%$ level $(P<0.01)$, ns - not significant

has also been obtained in summer squash unpollinated ovule culture (Shalaby, 2007). Obert et al. (2009) suggested that cells of flax tissue often react to in vitro conditions by rapid increase in the DNA amount in the course of prolonged culture; therefore it is necessary to transfer the callus to regeneration medium as soon as calli are big enough for manipulation.

\section{Conclusions}

1. For linseed (Linum usitatissimum L.) cultivars 'Dnepr-2 and 'Mikael' callus induction rate was the highest in the medium supplemented with $2 \mathrm{mg} \mathrm{l}^{-1}$ thidiazuron $(\mathrm{TDZ})+1 \mathrm{mg} \mathrm{l}^{-1} \alpha$-naphthylacetic acid (NAA) and $6 \%$ sucrose, while this combination of growth regulators significantly increased callogenesis in cultivars 'Atalante' and 'Indus-2' when medium was supplemented with 3\% sucrose and $3 \%$ maltose. A combination of $1 \mathrm{mg} \mathrm{l}^{-1} \mathrm{TDZ}+$ $2 \mathrm{mg} \mathrm{l}^{-1} \mathrm{NAA}$ and $6 \%$ sucrose promoted callus induction from ovaries of cultivars 'Norman' and 'Valuta-1', while a combination of $3 \%$ sucrose and $3 \%$ maltose in this medium was more suitable for callus induction from ovary of cultivars 'Lirina' and 'Zaltan-1'.

2. Induction medium supplemented with $2 \mathrm{mg}$ $\mathrm{l}^{-1} \mathrm{TDZ}+1 \mathrm{mg} \mathrm{l}^{-1} \mathrm{NAA}$ and $6 \%$ sucrose gave the highest shoot formation frequency from ovary-derived callus for cultivars 'Valuta-1', 'Mikael', 'Zaltan-1' and 'Dnepr-2'.

3 . The present study showed that $21.88 \%$ of plants regenerants obtained from ovary-derived callus were haploids.

Received 27022017

Accepted 13062017

\section{References}

1. Bartosova Z., Roux N., Pretova A. 2003. Green plants regenerated from ovary cultures in flax (Linum usitatissimum L.). Proceedings of $5^{\text {th }}$ international symposium Recent Advances in Plant Biotechnology and Plant Biotechnology: Progress and Developments. Stara Lesna, Slovak Republic, p. 65.

2. Bartošová Z., Obert B., Takáč T., Kormuták A., Pretová A. 2005 . Using enzyme polymorphism to identify the gametic origin of flax regenerants. Acta Biologica Cracoviensia series Botanica, 47: 173-178.

3. Burbulis N.,BlinstrubienėA.2011. Genotypic and exogenous factors affecting linseed (Linum usitatissimum L.) anther culture. Journal of Food, Agriculture and Environment, 9(3-4): 364-367.

4. Burbulis N., Blinstrubienè A., Sliesaravičius A., Venskutoniené E. 2005. Influence of genotype, growth regulators, sucrose level and preconditioning of donor plants on flax (Linum usitatissimum L.) anther culture. Acta Biologica Hungarica, 56: 323-331.

https://doi.org/10.1556/ABiol.56.2005.3-4.15
5. Burbulis N., Blinstrubienė A., Sliesaravičius A., Kuprienė R. 2007. Some factors affecting callus induction in ovary culture of flax (Linum usitatissimum L.). Biologija, 53: 21-23.

6. Chand S., Sahrawat A. K. 2007. Embryogenesis and plant regeneration from unpollinated ovary culture of Psoralea corvlifolia. Biologia Plantarum, 51: 223-228. https://doi.org/10.1007/s10535-007-0045-5

7. Chen Y., Dribnenki P. 2002. Effect of genotype and medium composition on flax Linum usitatissimum L. anther culture. Plant Cell Reports. 21: 204-207. https://doi.org/10.1007/s00299-002-0500-x

8. Compton M. E. 1994. Statistical methods suitable for the analysis of plant tissue culture data. Plant Cell, Tissue and Organ Culture, 37: 217-242.

9. Diao W. P., Jia Y. Y., Song H., Zhang X. Q., Lou Q. F., Chen J.F. 2009. Efficient embryo induction in cucumber ovary culture and homozygous identification of the regenerants using SSR markers. Scientia Horticulturae, 119: 246-251. https://doi.org/10.1016/j.scienta.2008.08.016

10. Finnie S. J., Powell W., Dyer A. F. 1989. The effect of carbohydrate composition and concentration on anther culture response in barley (Hordeum vulgare L.). Plant Breeding. 103: 110-118. https://doi.org/10.1111/j.1439-0523.1989.tb00358.x

11. Ghosh A., Hossain M. M., Sharma M. 2014. Mass propagation of Cymbidium giganteum Wall. ex Lindl. using in vitro seedlings. Indian Journal of Experimental Biology, 52: 905-911.

12. Guo B., Abbasi B. H., Zeb A., Xu L. L., Wei Y. H. 2011. Thidiazuron: a multi-dimensional plant growth regulator. African Journal of Biotechnology, 10: 8984-9000. https://doi.org/10.5897/AJB11.636

13. Gurel S., Gurel E., Kaya Z. 2000. Double haploid plant production from unpollinated ovules of sugar beet (Beta vulgaris L.). Plant Cell Renorts. 19: 1155-1159. https://doi.org/10.1007/s002990000248

14. Kamštaityte D., Stanys V. 2002. Pathways of onion regeneration via flower and ovary culture. ZemdirbysteAgriculture, 2: 245-250.

15. Lata H., Chandra S., Khan I., ElSohly M. A. 2009. Thidiazuron-induced high-frequency direct shoot organogenesis of Cannabis sativa L. In Vitro Cellular and Developmental Biology - Plant, 45: 12-19. https://doi.org/10.1007/s11627-008-9167-5

16. Mikelsone A., Grauda D., Stramkale V., Ornicans R., Rashal I. 2013. Using anther culture method for flax breeding intensification. $9^{\text {th }}$ international scientific and practical conference Environment. Technology. Resources, vol. 1, p. 149-151.

17. Millam S., Davidson D., Powell W. 1992. The use of flax (Linum usitatissimum) as a model system for studies on organogenesis in vitro: the effect of different carbohydrates. Plant Cell. Tissue and Organ Culture, 28: 163-166. https://doi.org/10.1007/BF00055512

18. Mundhara R., Rashid A. 2006. TDZ-induced triple-response and shoot formation on intact seedlings of Linum, putative role of ethvlene in regeneration. Plant Science. 170: 185-190. https://doi.org/10.1016/j.plantsci.2005.06.015

19. Murashige T., Skoog F. 1962. A revised medium for rapid growth and bioassay with tobacco tissue cultures. Physiologia Plantarum, 15: 473-497. https://doi.org/10.1111/j.1399-3054.1962.tb08052.x 
20. Navarro-Alvarez W., Baenziger P. S., Eskridge K. M., Shilton D. R., Gustafson V. D., Hugo M. 1994. Effect of sugars in wheat anther culture media. Plant Breeding, 112: 53-62. https://doi.org/10.1111/j.1439-0523.1994.tb01276.x

21. Obert B., Dedicova B., Hricova A., Samaj J., Pretova A. 2004 (a). Flax anther culture: effect of genotype, cold treatment and media. Plant Cell. Tissue and Organ Culture, 79: 233-238. https://doi.org/10.1007/s11240-004-0664-x

22. Obert B., Bartosova Z., Pretova A. 2004 (b). Dihaploid production in flax by anther and ovary cultures. Journal of Natural Fibers, 1: 1-14.

https://doi.org/10.1300/J395v01n03_01

23. Obert B., Zackova Z., Samaj J., Pretova A. 2009. Doubled haploid production in flax (Linum usitatissimum L.). Biotechnology Advances, 27: 371-375. https://doi.org/10.1016/j.biotechadv.2009.02.004

24. Pavelek M., Tejklova E., Bjelkova M. 2015. Flax and linseed. Cruz V. M. V., Dierig D. A. (eds.). Industrial crops - breeding for bioenergy and bionroducts. New York, ISSA, p. 233-264. https://doi.org/10.1007/978-1-4939-1447-0_11

25. Pretova A., Obert B. 2000. Progress in flax androgenesis. Bohanec B. (ed.) Biotechnological approaches for utilization of gametic cells. Proceedings of the COST 824 final meeting. Bled, Slovenia, p. 165-169.

26. Pretova A., Obert B., Bartosova Z. 2006. Haploid formation in maize, harley, flax and notato. Protonlasma, 228: 107-114. https://doi.org/10.1007/s00709-006-0170-6

27. Redha A., Talaat A. 2008. Improvement of green plant regeneration by manipulation of anther culture induction medium of hexaploid wheat. Plant Cell, Tissue and Organ Culture, 92: 141-146. https://doi.org/10.1007/s11240-007-9315-3

28. Rutkowska-Krause I., Mankowska G., Lukaszewicz M., Szopa J. 2003. Regeneration of flax (Linum usitatissimum L.) plants from anther culture and somatic tissue with increased resistance to Fusarium oxvsporum. Plant Cell Reports, 22: 110-116. https://doi.org/10.1007/s00299-003-0662-1

29. Shalaby T. A. 2007. Factors affecting haploid induction through in vitro gynogenesis in summer squash (Cucurbita pepo L.). Scientia Horticulturae. 115: 1-6. https://doi.org/10.1016/j.scienta.2007.07.008
30. Sibi M. L., Kobaissi A., Shekafandeh A. 2001. Green haploid plants from unpollinated ovary culture in tetraploid wheat (Triticum durum Defs.). Euphytica, 122: 351-359. https://doi.org/10.1023/A:1012991325228

31. Tang F., Tao Y., Zhao T., Wang G. 2006. In vitro production of haploid and double haploid plants from pollinated ovaries of maize (Zea mays). Plant Cell, Tissue and Organ Culture, 84: 233-237.

https://doi.org/10.1007/s11240-005-9017-7

32. Tarakanovas P., Raudonius S. 2003. Agronominių tyrimų duomenų statistinè analizè taikant kompiuterines programas ANOVA, STAT, SPLIT-PLOT iš paketo SELEKCIJA ir IRRISTAT. Lithuanian University of Agriculture, $58 \mathrm{p}$. (in Lithuanian).

33. Tejklova E. 1998. Study of anther culture in flax (Linum usitatissimum L.). Proceedings of the Bast Fibrous Plants Today and Tomorrow. St. Petersburg, Russia, p. 202-209.

34. Tolkachev O. N., Zhuchenko A. A. 2000. Biologically active substances of flax: medicinal and nutritional properties. Pharmaceutical Chemistry Journal. 34 (7): 360-367. https://doi.org/10.1023/A:1005217407453

35. Vujović T., Ružić D., Cerović R., Momirović G. S. 2010. Adventitious regeneration in blackberry (Rubus fruticosus L.) and assessment of genetic stability in regenerants. Plant Growth Regulators, 61: 265-275. https://doi.org/10.1007/s10725-010-9474-9

36. Wedzony M., Forster B. P., Zur I., Golemiec E., SzechynskaHebda M., Dubas E., Gotebiowska G. 2009. Progress in doubled haploid technology in higher plants. Touraev A. et al. (eds.). Advances in haploid production in higher plants, p. 1-34. https://doi.org/10.1007/978-1-4020-8854-4_1

37. Yadava D. K., Vasudev S., Singh N., Mohapatra T., Prabhu K. V. 2012. Breeding major oil crops: present status and future research needs. Gupta S. K. (ed.). Technological innovations in maior world oil crops. vol. 1: Breeding, p. 24-25. https://doi.org/10.1007/978-1-4614-0356-2_2

38. Zuk M., Richter D., Matula J., Szopa J. 2015. Linseed, the multipurpose plant. Industrial Crops and Products, 75: 165-177. https://doi.org/10.1016/j.indcrop.2015.05.005

ISSN 1392-3196 / e-ISSN 2335-8947

Zemdirbyste-Agriculture, vol. 104, No. 3 (2017), p. 243-248

DOI 10.13080/z-a.2017.104.031

\title{
Genotipo ir egzogeninių veiksnių įtaka sėjamojo lino mezginių kultūrai
}

\author{
A. Blinstrubienè, N. Burbulis, R. Masienè
}

Aleksandro Stulginskio universitetas

\section{Santrauka}

Tirta genotipo, augimo reguliatorių ir angliavandenių tipo ịtaka sėmeninio lino (Linum usitatissimum L.) aštuonių veislių kaliaus indukcijai ir netiesioginei ūglių regeneracijai izoliuotų mezginių kultūroje. Kaliaus genezė varijavo nuo 9,17 iki $100 \%$, priklausomai nuo genotipo ir maitinamosios terpès saveikos. Derinys sacharozè + maltozè esmingai didino trijų arba keturių tirtų veislių kaliaus indukciją, priklausomai nuo augimo reguliatorių derinio indukcijos maitinamojoje terpèje. Penkių iš aštuonių tirtų veislių mezginių indukuotas kalius ūglius formavo 4,17$75,00 \%$ dažniu, kitos trys ūglių neformavo. Sacharozę indukcijos terpèje pakeitus deriniu sacharozè + maltozè, ūglių susiformavimo dažnis regeneracijos terpejje esmingai sumažejo arba buvo visiškai slopinamas. Veislès 'Mikael' izoliuotų mezginių suformuotas kalius ūglius formavo esmingai didžiausiu dažniu - 52,50\%. Dispersinė analizè parodè, kad kaliaus indukcijos ir ūglių formavimosi dažnis priklauso nuo veislès, augimo reguliatorių derinio ir angliavandenių tipo bei jų sąveikos. Daugeliu atvejų didesnis ūglių susiformavo dažnis gautas iš kaliaus, indukuoto indukcijos terpeje, papildytoje $2 \mathrm{mg} \mathrm{l}^{-1} 1$-fenil-3-(1,2,3-tiadiazol-5-il)-karbamido (TDZ) $+1 \mathrm{mg} \mathrm{l}^{-1}$ $\alpha$ naftilacto rūgšties (NAR) ir $6 \%$ sacharozès. Citologiniais tyrimais nustatyta, kad 21,88 \% augalų regenerantų buvo haploidai, $78,12 \%$ - diploidai ir miksoploidai.

Reikšminiai žodžiai: angliavandeniai, augimo reguliatoriai, genotipas, Linum usitatissimum, morfogeninė galia, mezginių kultūra. 